Final technical Report - Dated December 14, 2001

\title{
Development of an Enhanced Two-Phase Production System at The Geysers Geothermal Field, California
}

\author{
In response for
}

\section{ENHANCED GEOTHERMAL SYSTEMS PROJECT DEVELOPMENT}

\section{U.S. Department of Energy - Financial Assistance Award \#DE-FG07-00ID13992}

\section{SUMMARY}

A method was developed to enhance geothermal steam production from two-phase wells at The Geysers Geothermal Field. The beneficial result was increased geothermal production that was easily and economically delivered to the power plant.

The proposed concept was to design, install, and test special down-hole and surface equipment intended to allow hot water to be produced to the surface. Producing the water allowed for increased (enhanced) steam flow from the existing production well. The second benefit was that hot water $(>275 \mathrm{~F})$ became available for augmented injection.

The resultant successful installation of well equipment on well B-6 (See Figure 1) now allows for both the production of steam or the injection of water in order to enhance geothermal production. Following the EGS Installation, steam production was increased by $\sim 15,000$ pounds per hour or about $1 \mathrm{MW}$. After 18 months of steam production, the well was then successfully converted to injection during May 2001.

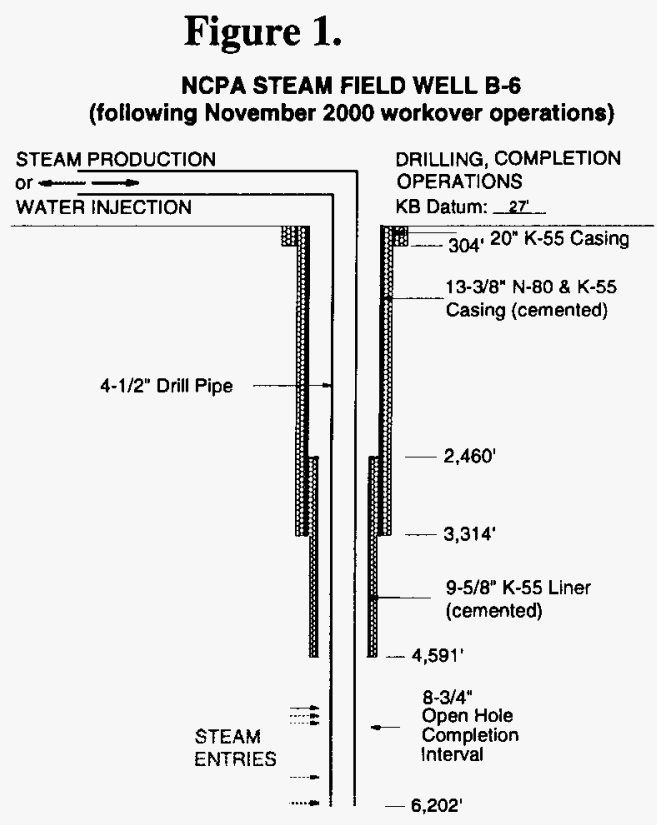




\section{BACKGROUND}

Enhanced geothermal systems utilize either hot water or steam to transport heat to the surface. At The Geysers Geothermal System, injection has become an increasingly important heat recovery mechanism. Water injected into wells is used to mine heat that continues to remain in the geothermal reservoir matrix. The injected water flashes and often becomes superheated. The injection-derived-steam is then produced by the nearby offset producing wells. Now that there have been several years of increased injection at The Geysers, the occurrences of water breakthrough to the off-set steam wells has increased. In these cases, the water has traveled through a fracture that provides a "short-circuit" and it has entered the offset steam well before having flashed to steam.

The breakthrough of water has several detrimental effects to a steam well: 1) the water causes the steam well to reduce steam flow, due to water accumulating in the well bore, 2) the steam being produced is cooler than before, and 3) the water brings silica and other contaminants into the main steam path. Consequently, a method is required to economically and effectively remove water from these steam wells. The beneficial result will be increased (enhanced) geothermal production that can be easily and economically delivered to the existing power plants.

\section{TECHNICAL DISCUSSION}

A drill rig was utilized to install the small diameter tubing into well B-6 in order to increase the ability of the steam flow to lift the water to the surface. The EGS installation occurred between October and November 2000. A summary of the well workover history is shown in Appendix A.

\section{Well Selection}

An example of injection breakthrough to an off-set steam well is P-1 injection communicating with B-6 production. These two wells form a couplet, in which injectate from P-1 is boiled and produced by the offset steam well. However, a short-circuit exists that allows for water to travel to B-6 without boiling. The water breakthrough actually "killed" the well and eliminated steam flow as shown on Fig. 2

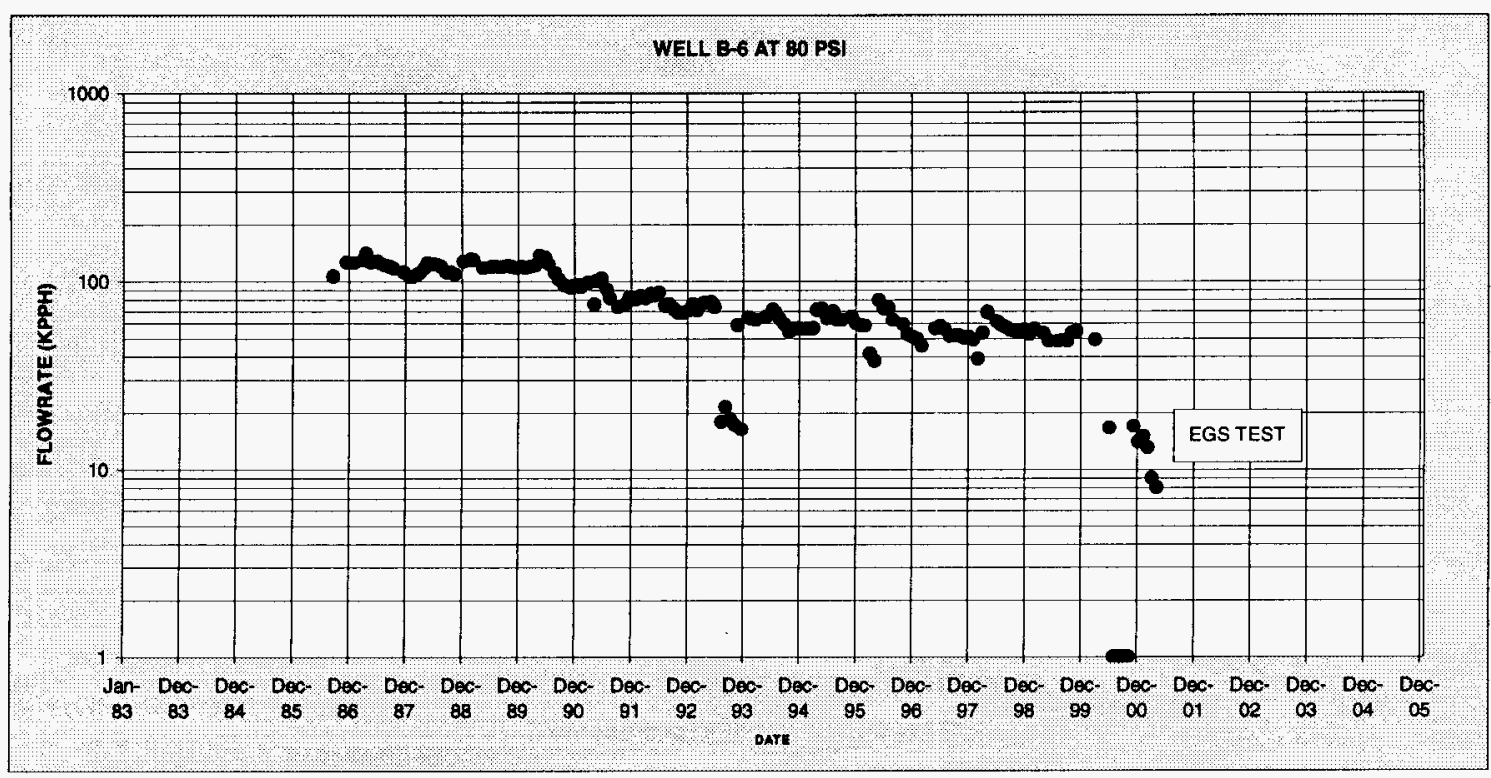

Figure 2. 
Well B-6 was originally completed in 1977 . It was completed as a steam producer and has been on-line since 1986. The well benefited from injection into well

Figure 3. Area of Well B-6

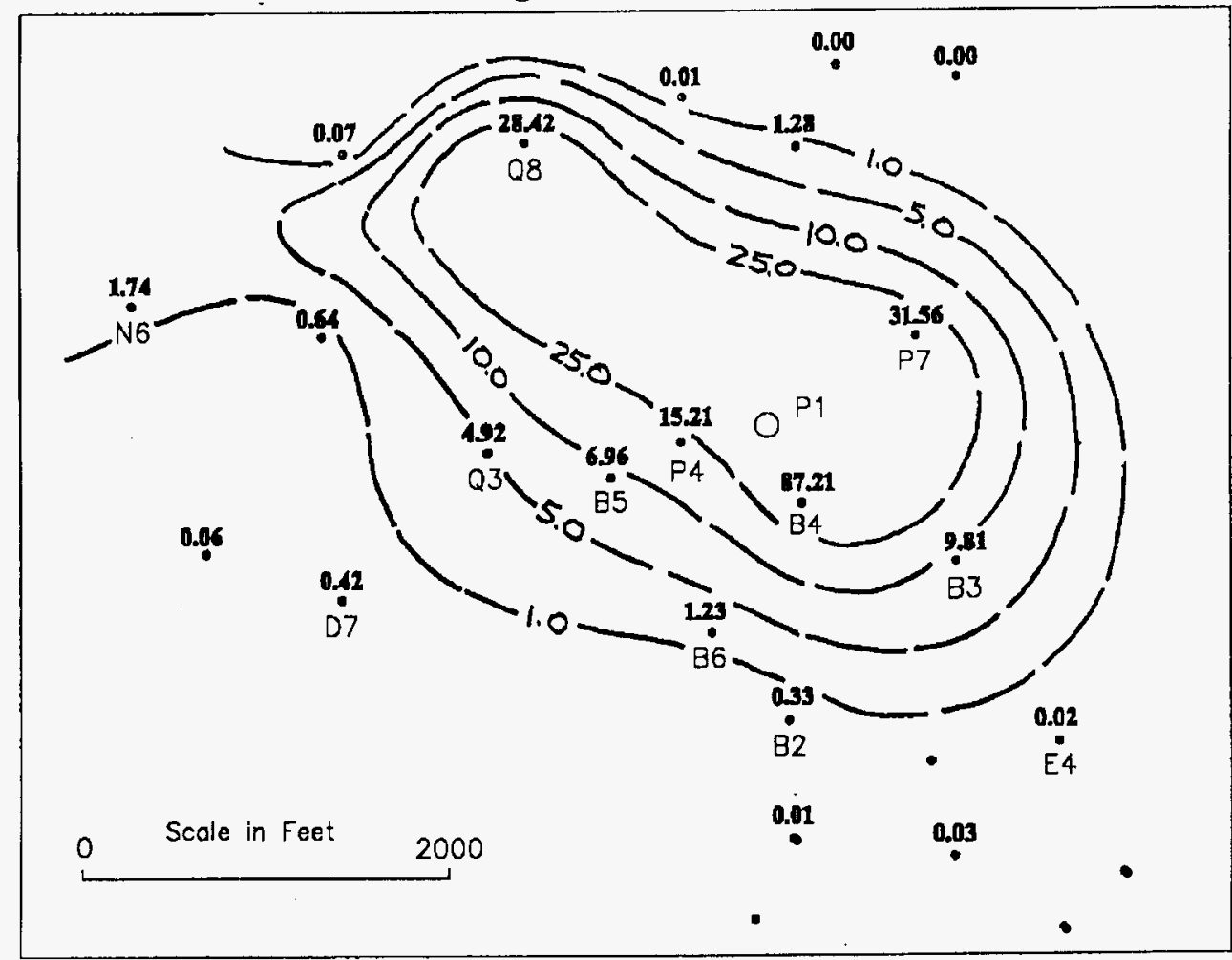

\section{Cumulative Recovery of R-23 Tracer (in Pounds) Day 56 following August 18, 1998 Injection}

P-1 that started in early 1998. A tracer test conducted on well P1 in 1998 indicated that a significant amount of the injection derived steam was being produced by many of the off-set steam wells, including B-6, as shown in Figure 3. Because of the beneficial response to injection in well P-1, it was not an option to redistribute injectate to another well once water breakthrough occurred into B-6. Therefore an alternative well completion into well B-6 was installed during a rig workover, August - October 2000 which allowed for enhanced geothermal steam production.

Steam production at The Geysers typically occurs from wells that are completed with an openhole interval below cemented casing. Well diameters within the open-hole completion interval typically range between 8.75 and 12.25 inches. Depths of the steam entries can range between 2,500 and $10,000+$ feet with multiple steam and/or water entries per well. The wells and production surface equipment are designed for single-phase steam production at a backpressure that is controlled by the power plant operations and by the gathering system mechanics. Typically this pressure is 90 to 120 psig. Well B-6, the test well, is shown on Figure 1.

When injected water breaks through to a steam well, the water reduces steam flow and requires that special water-handling separators be placed on the wellhead. If the steam has sufficient velocity to lift the water from the well bore, the water is produced as a two-phase mixture to the surface. But more often the steam has insufficient velocity to effectively lift the water out of the 
well bore. In these cases the first indication at the surface of water breakthrough into the well bore is an observed unusually sudden decrease in steam flow, because water has accumulated in the deeper section of the well bore and has actually reduced in not eliminated any steam production from the deeper steam entries. In these cases the two main factors for why the steam has insufficient energy to lift the water is because of the relatively large well bore diameter, and because of the existing operating backpressure at the well head is high compared to the reservoir pressure.

Simply put, the concept of how to overcome this problem is to necessarily alter either or both of these two conditions. The inserting of smaller diameter tubing into the well will reduce the effective well diameter, increasing the ability of the steam flow to lift the water to the surface. Secondly, the surface equipment can be designed to minimize the backpressure at the well head, by use of for example a cyclonic separator tank that can be operated at pressures as low as atmospheric.

\section{Well Tubing}

One of the critical variables of this Project is to determine a workable tubing diameter. From experience 2-7/8" and 4-1/2" tubing are common diameters for this type of application.

Additionally, these sizes are readily available.

A string of $27 / 8$ " drill pipe was inserted into the well and a flow test was conducted at three depths: $5,025 \mathrm{ft}, 6,025 \mathrm{ft}$. and $6,995 \mathrm{ft}$. The ability of the tubing to lift water at the various depths was determined by a flow test. The well was allowed to flow through the drill pipe to a tank and the volume of water was gauged over time. Figure 4 shows the results of that test.

\section{Figure 4.}

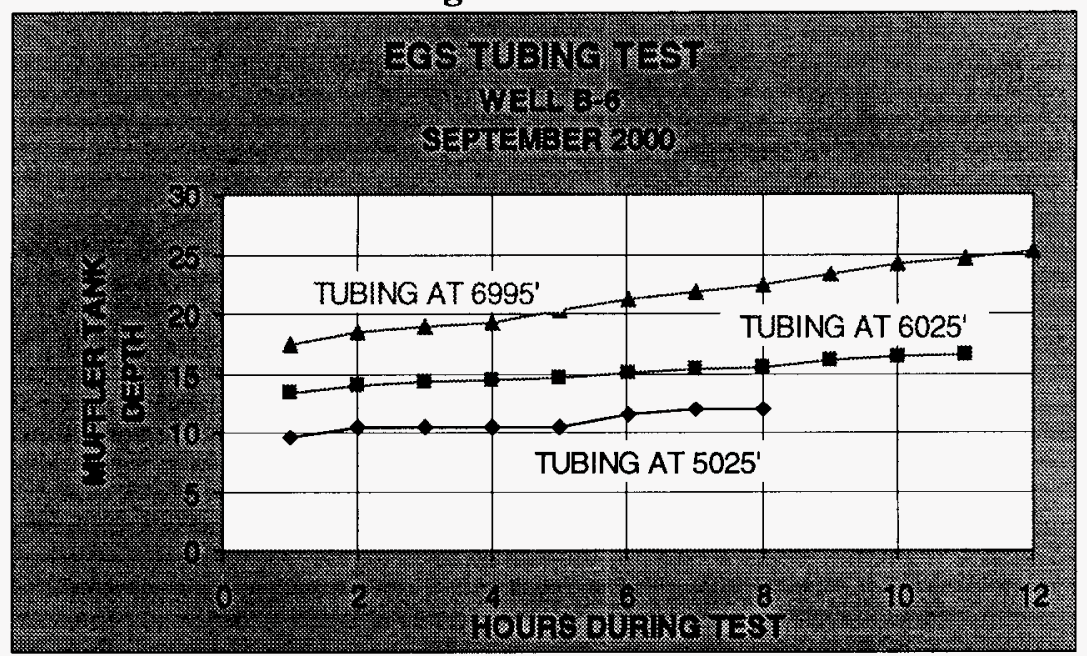

The test indicated that the deepest setting was the most successful at lifting fluids. Therefore, it was determined that tubing should be set at the deepest depth possible, with sufficient perforations to allow for water to enter the tubing, even if the bottom of the tubing is plugged. Later, $41 / 2$ " tubing showed that water could successfully be lifted with the larger diameter pipe while allowing for increased steam flow. Therefore $4 \frac{1 / 2}{2}$ "pipe was permanently installed in the well to enhance geothermal steam production.

\section{Wellhead Hanging Tool}

To install the tubing in the wellhead, a special hanging tool needed to be fabricated that can support the weight of $70,000 \mathrm{lbs}$. of tubing but without interfering with well control of both the 
tubing and the annular flow. Although this device must be specially fabricated, there are well field services companies that will readily provide this type of device. Figure 5 shows the special wellhead-hanging tool developed for this application. It is important to note that both the annulus and tubing are available for production utilizing this wellhead tool.

\section{Figure 5 \\ Wellhead Hanging Tool}

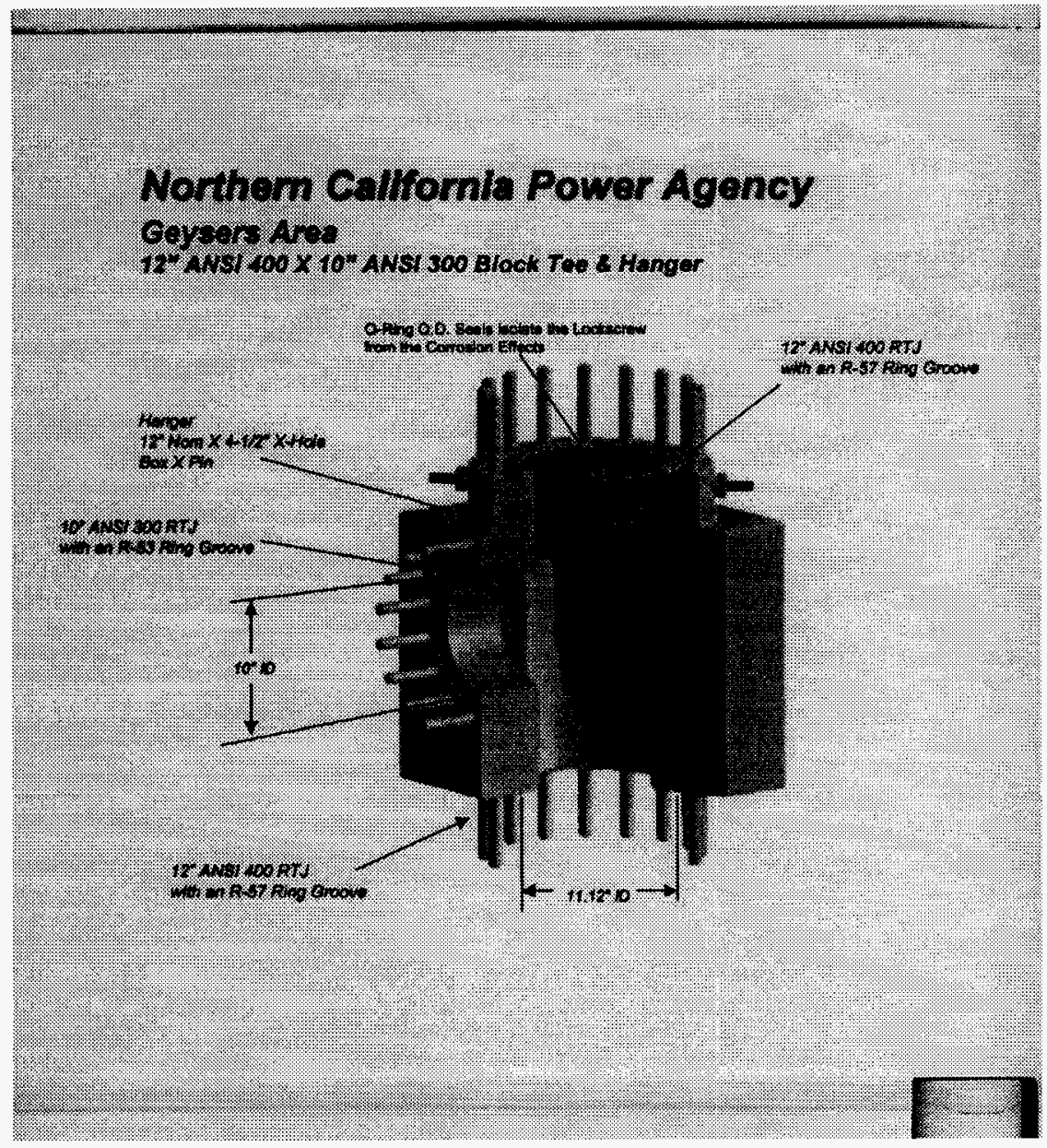

\section{Surface Separator and Gathering System}

The two-phase stream gathering equipment was already in place. The water was separated and collected by typical hot water pipeline systems at The Geysers. The stream flow was directed to a cyclonic separator. The hot water was produced to the injection system for reinjection. The steam flow is from the 10" side valve of the hanging tool, and water flow is from the tubing string. From the wellhead, the steam was directed to NCPA's Plant 2. The water production was sufficient to keep the well from loading-up but was insufficient to measure any significant volume of water flow.

\section{Control Equipment}

The steam gathering control and measurement equipment was already in place and includes pressure, temperature and flow measurement devices. 
Temperature \& Pressure Surveys

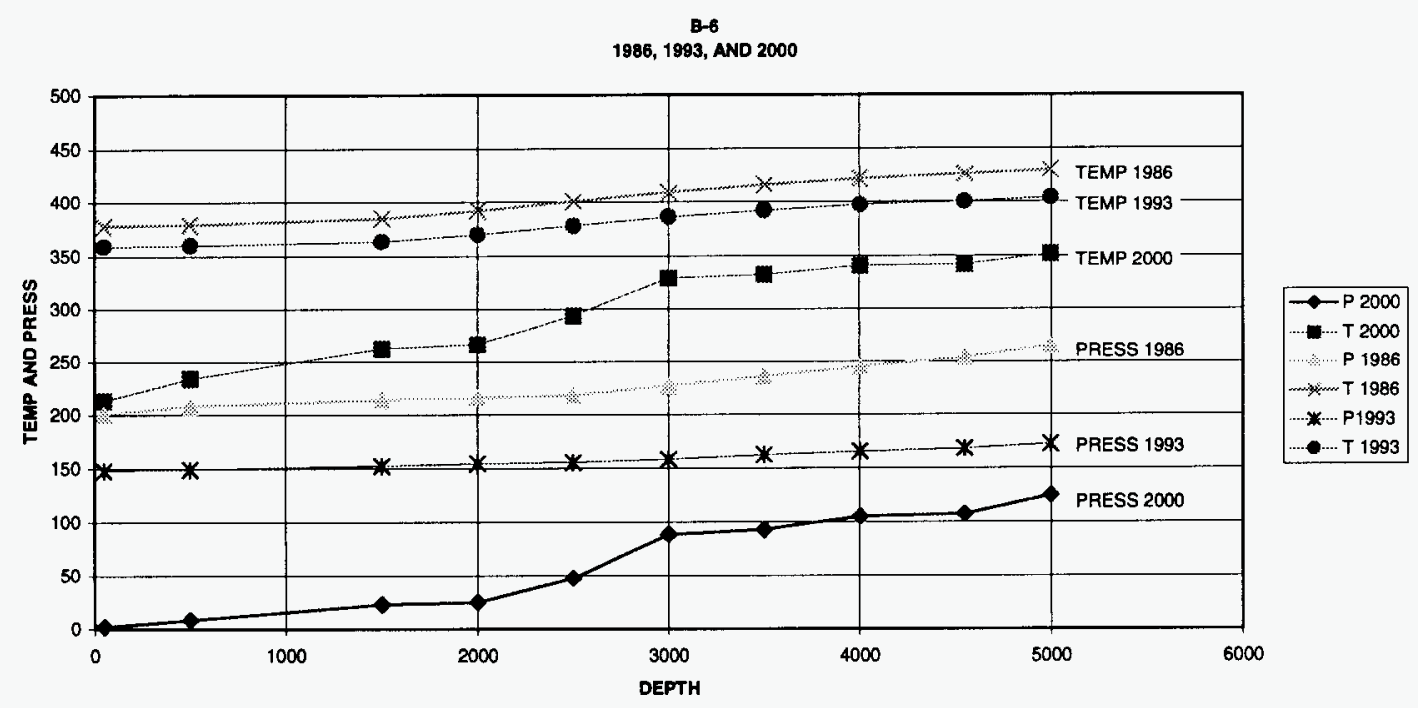

Figure 6 -Pressure and Temperature History

Prior To Installation of EGS System

Figure 6 is the P\&T history of well B-6 from the surface to 5,000 ft. Surveys below that depth were not possible prior to the installation of the EGS due to a restriction in the open-hole. The surveys showed the dramatic cooling of the well concurrent with the water breakthrough period.

Following the installation of the EGS System, surveys were conducted to determine the effectiveness of removing the water from the wellbore and heating the well.

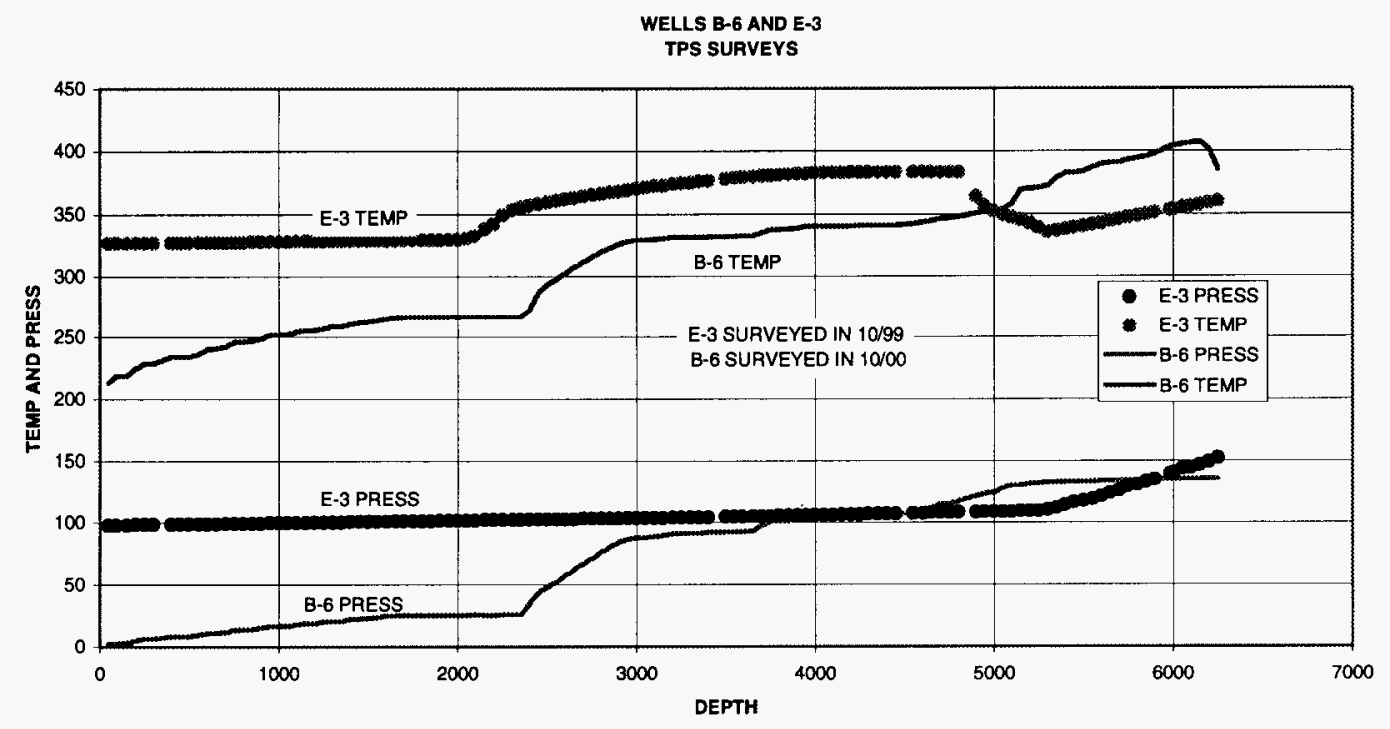

Figure 7 -Pressure and Temperature Survey on B-6

Following Installation of EGS System

Figure 7 compares the P\&T survey on well B- 6 following the installation of the EGS system with a similar survey on well E-3. Note that the temperature of E-3 is also affected by water breakthrough. B-6 temperature is $>400 \mathrm{~F}$ at depth indicating the success of the tubing in 
keeping the well from loading with water. A temperature reversal occurred at $6,175^{\prime}$ indicating the cooler water was still entering the wellbore and being heated by more shallow steam as the well was produced.

\section{Extended Pressure Monitoring}

In order to determine the long-term success of the EGS wellbore system to prevent the well from loading with unflashed injectate, a pressure monitoring system was installed. It was found that the $41 / 2$ " pipe was ideal for installing and maintaining a capillary pressure monitoring system as shown on Figure 8. The tubing showed that the bottom-hole producing pressure was constant during the 12 month observation period at $\sim 125 \mathrm{psig}$, proving that the well was not loaded with water.

Figure 8 -Pressure Monitoring System on Well B-6 Following Installation of EGS System

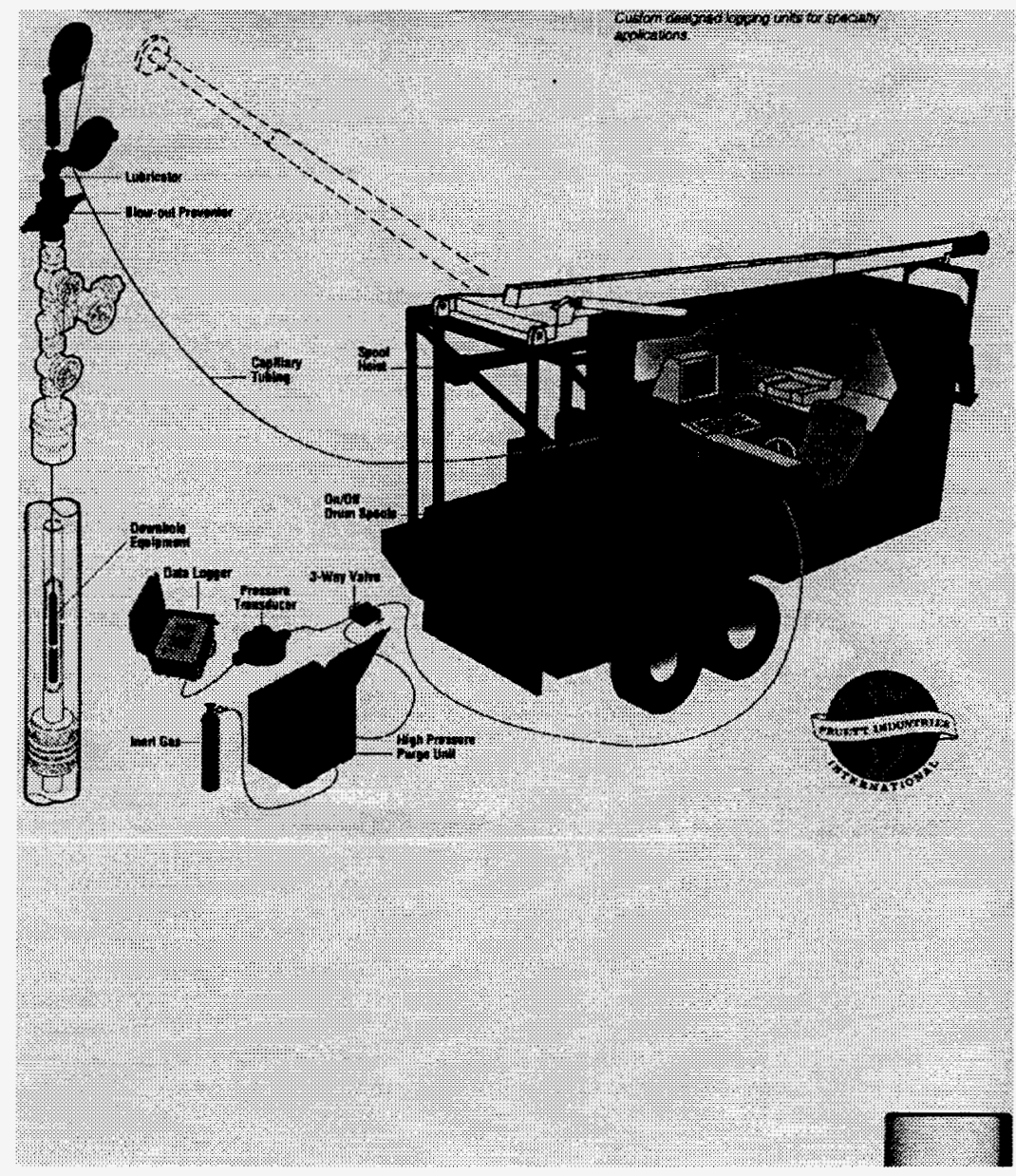




\section{APPENDIX A WELL WORKOVER HISTORY}

\section{OPERATOR: NORTHERN CALIFORNIA POWER AGENCY}

WELL: $\quad$ B-6 (17D-1)

LEASE: CA -949 COUNTY: Lake

LOCATION: $\quad$ Section 1, T10N, R8W, MD B\& M
N $395,139.8$
E $1,799,199.1$

ELEVATION: 3,209 Feet KB Datum

DATE

OPERATIONS

\begin{tabular}{|c|c|}
\hline $08 / 11 / 2000$ & Prep B-6 Location \& Load out NCPA Rig off P-3 \\
\hline $08 / 14-15,2000$ & Rig off Sat. \& Sun., 8/12 \& 8/13, 2000. Rig up NCPA Rig on CA-949, B-6 \\
\hline $08 / 16 / 2000$ & $\begin{array}{l}\text { Rig up on B-6, Derrick in Air @ 2:00 p.m. Set in muffler \& blooie line. Remove floor and } \\
\text { rotary table \& change out spool on B.O.P. }\end{array}$ \\
\hline $08 / 17 / 2000$ & $\begin{array}{l}\text { Nipple-up BOE \& Nipple-up Blooie Line \& Accum. Line. Function-Test BOE. Set in rotary } \\
\text { table \& floor. Pick-up swivel \& make up Kelly. Rig up muffler sump pump. Open well @ } \\
\text { 12:30 PM and flow well. Rig up floor \& tongs. Pickup new D.A. \& make up. Pickup 4-1/2 } \\
\text { D.P. \& RIH. }\end{array}$ \\
\hline $08 / 18 / 2000$ & $\begin{array}{l}\text { Pick up 4-1/2 DP to } 2460 \text { ’ \& tighten Kelly. Blow well @ 2447’, top of hanger @ } 2460 \text { ’. } \\
\text { POH. Remove 4-1/2" Rot. Rubber, brk 12-1/4 bit \& make-up 8-1/2 mill tooth. Install 4-1/2 } \\
\text { Rot. Rubber. RIH T/Hanger \& pickup 4-1/2 DP T/5605. Blow well, pickup 4-1/2 DP } \\
\text { T/6190. Blow well, pickup 4-1/2 DP \& blow well @ 7040. Hope making water, } 18 \text { BLBs } \\
\text { Per hour. }\end{array}$ \\
\hline $08 / 19 / 2000$ & $\begin{array}{l}\text { POH to shoe @ } 4591 \text {. Flow well. RIH to } 7040 \& \text { \& } 4591 \& \text { break Kelly. L/D Drill pipe, } \\
\text { hookup vent-line from B-6 to B-5, L/D Drill Pipe. Hole making water, avg. } 13 \text { BLBs per } \\
\text { hour. }\end{array}$ \\
\hline $08 / 20 / 2000$ & $\begin{array}{l}\text { L/D Drill Pipe \& L/D Drill collars. L/D swivel \& Kelly. Close in well @ 7:30 a.m. Put on } \\
\text { vent-line from B-6 to B-5 @ 7:45 a.m. Well on production. Rig down NCPA Rig. Rig } \\
\text { Release @ 6:00 p.m. }\end{array}$ \\
\hline $08 / 21 / 2000$ & $\begin{array}{l}\text { Clean out muffler tank, clean out Rig Day Tank, Cleanup Rig. Secure NCPA Drill Rig for } \\
\text { Downtime. }\end{array}$ \\
\hline $09 / 11 / 2000$ & $\begin{array}{l}\text { Start up Rig, setout floor \& table. Nipple down BOP \& take out spools in BOP. Set in 4-1/2" } \\
\text { Drill Pipe landing spool \& top 12" WKM valve for capillary testing with 2-7/8" drill pipe. } \\
\text { Set in BOP, nipple-up. Nipple up blooie-line \& set-in table \& floor. Center BOPE, remove } \\
\text { 3" vent line f/B-6. Install kill line \& remove 4-1/2" Ram Rubbers \& 4-1/2" steel Ram's. }\end{array}$ \\
\hline $09 / 12 / 2000$ & $\begin{array}{l}\text { Nipple down \#1 Eng. \& Load out \& startup rig. Set in \#4 Eng. Install 2-7/8" pipe Ram, } 2 \text { set } \\
\text { of Ram's. Function test BOP rig up f/2-7/8 Drill pipe. Open up well \& let flow @ 1:00 p.m. } \\
\text { Flow well f/water, shut in well \& dry-watch. }\end{array}$ \\
\hline $09 / 13 / 2000$ & Monitor well. Open \& flow B-6 well. Rig-up to run 2-7/8" DP. Mk-up 3-1/2" Rot. Rubber. \\
\hline
\end{tabular}




\begin{tabular}{|c|c|}
\hline & $\begin{array}{l}\text { Load walk \& strap 2-7/8 DP. Do safety meeting before RIH with 2-7/8" DP. Install Rot. } \\
\text { Rubber. RIH } 3 \text { Jts. Of 2-7/8" Perf. D.P. RIH 2-7/8" DP to } 4998 \text {. Mk-up crossover subs \& } \\
\text { DP land doughnut. Pk-up } 1 \text { jt. of 4-1/2" DP to land doughnut with. Try to land doughnut. } \\
\text { NG. Mk-up safety valve on top 4-1/2" DP \& kill well. Try to land doughnut. Won't go } \\
\text { through 12" WKM working valve. Pull up through BOP. Shut DP Ram's \& monitor well. }\end{array}$ \\
\hline $09 / 15 / 2000$ & $\begin{array}{l}\text { Monitor shut-in Wellhead pressure \& Open up top 12" WKM master working valve \& } \\
\text { monitor water. Flow rate \& well head-pressure doing capillary testing with } 27 / 8 \text { " DP, } \\
\text { (wellhead pressure is at } 125 \text { psi) }\end{array}$ \\
\hline $09 / 18 / 2000$ & $\begin{array}{l}\text { Startup Rig. Install } 2 \text { sets of 2-7/8" BOP Ram Rubbers. Monitor wellhead pressure. Open } \\
\text { well @ 10:15 a.m. Wellhead pressure close-in } 130 \text { psi. Monitor wellhead pressure \& water } \\
\text { flow on capillary testing. Kill well @ 12:00. Pull drill pipe, doughnut \& Ly-down \& } \\
\text { crossover subs. Install 3-1/2" Rot. Rubber. Mk-up new crossover sub \& landing doughnut. } \\
\text { Land doughnut inside landing spool @ } 6025 \text {. Shut in well \& 3:30 p.m. Monitor shut-in } \\
\text { pressure. Wellhead pressure flowing } 125 \text { psi. 1-1/2 bbl water per hour. }\end{array}$ \\
\hline $09 / 19 / 2000$ & $\begin{array}{l}\text { Monitor shut-in pressure. Open well @ 12:00. Flow well \& monitor wellhead pressure \& } \\
\text { monitor H2) flow. Doing capillary testing @ 6025'. Shut well in @ 10:00 p.m. Monitor } \\
\text { wellhead pressure. Wellhead pressure } 125 \text { psi; H2O 1-1/4 bbl per hr. }\end{array}$ \\
\hline $09 / 20 / 2000$ & $\begin{array}{l}\text { Monitor wellhead pressure. Kill well. Lay down landing doughnut \& pk-up 2-7/8" DP to } \\
6970 . \text { Mk-up landing doughnut \& land doughnut inside landing spool @ 6095'. Close top } \\
\text { 12" working Master Valve. Monitor wellhead shut-in pressure. }\end{array}$ \\
\hline $09 / 21 / 2000$ & $\begin{array}{l}\text { Monitor wellhead shut-in pressure \& open well @ 11:00 a.m. Monitor wellhead pressure \& } \\
\text { H2O flow @ muffler tank. Doing capillary testing @ 6,995'. Close top working 12" Master } \\
\text { Valve. Secure Rig. }\end{array}$ \\
\hline $09 / 22 / 2000$ & $\begin{array}{l}\text { Startup Rig. Wait on Welaco, Rig-up Welaco. Fluid level @ 6729'. Rig up vent line \& vent } \\
\text { through (2) three-inch wing valves to B-5. Shut rig down \& secure. }\end{array}$ \\
\hline $10 / 03 / 2000$ & $\begin{array}{l}\text { Nipple down vent-line on B-6. Rig up Welaco to run shotgun Log. Run fluid level @ } 1361 . \\
\text { Rig down Welaco \& nipple up vent line on B-6. }\end{array}$ \\
\hline \begin{tabular}{|l}
$10 / 10 / 2000$ \\
\end{tabular} & $\begin{array}{l}\text { Startup NCPA Rig. Held Safety meeting w/Pruett Wire line men. Rig up Pruett. Run in } \\
\text { Pressure Capillary tubing log. Tool Stop @ 3200', pull to } 2450 \text {, line parted. Rig down } \\
\text { Pruett. Secure NCPA Rig. }\end{array}$ \\
\hline $10 / 11 / 2000$ & $\begin{array}{l}\text { Startup NCPA Rig. Rig up to install } 10 \text { " Master Valve on side of capillary landing spool. } \\
\text { Kill well \& remove blank flange on side of capillary landing spool. Install } 10 \text { " Master valve, } \\
\text { rig up to pull drill pipe landing doughnut, pull landing doughnut. Lay down } 2-7 / 8^{\prime \prime} \text { drill pipe, } \\
60 \text { jts. Total. No wire line found inside pipe. Lay down 1820' drill pipe. Reset drill pipe } \\
\text { landing doughnut. Close } 12 \text { " WKM valve \& secure NCPA Rig. }\end{array}$ \\
\hline $10 / 12 / 2000$ & $\begin{array}{l}\text { Startup NCPA Rig \& kill well. Open WKM Valve \& pull drill pipe landing doughnut \& rig } \\
\text { up Bill's Casing Crew to lay down 2-7/8" drill pipe. Lay down } 43 \text { jts. Of 2-7/8" drill pipe. } \\
\text { Make-up drill pipe landing doughnut \& land. Drill pipe hung @ 3770'. Rig down Bill's } \\
\text { Casing. Hook-up 10" blowdown line on landing spool \& hook-up 3" vent line. Close 12" } \\
\text { top WKM valve \& secure rig. }\end{array}$ \\
\hline $10 / 23 / 2000$ & $\begin{array}{l}\text { Start-up NCPA rig. Nipple down 10" blowdown line. Nipple down 3" ventline \& hook up } \\
\text { kill line. Kill well. Clear V-door. Open WKM valve, pull drill pipe landing doughnut. } \\
\text { Install used Rot. Rubber \& rig up Bill's Casing crew. Lay-down 2-7/8" DP. Close well in } \\
\text { and rig down Casing crew. Remove Rot. Rubber. Rig up to run 4-1/2" DP. Remove 2-7/8" } \\
\text { Ram's on single gate. Install 4-1/2" steel Ram's. Secure NCPA Rig. (Lay down total of 2- } \\
7 / 8 \text { " } 120 \text { jts.) }\end{array}$ \\
\hline
\end{tabular}




\begin{tabular}{|c|c|}
\hline $10 / 24 / 2000$ & $\begin{array}{l}\text { Didn't find any capillary tubing wire or tool inside } 2-7 / 8 \text { " DP. Remove } 2-7 / 8 \text { " BOPE Ram } \\
\text { Rubbers, install 4-1/2" BOPE Ram Rubbers \& function test. Open up well \& flow clean box } \\
\& \text { pin on 4-1/2" Red band DP to run in hole. Strap 4-1/2" drill pipe. Install Rot. Rubber, } \\
\text { Mule-shoe first jt. of 4-1/2" pipe \& pickup 4-1/2" DP mule-shoe to RIH on bottom. Picking } \\
\text { up 4-1/2" DP to 4803. Install safety valve \& secure rig. }\end{array}$ \\
\hline $10 / 25 / 2000$ & $\begin{array}{l}\text { Pickup 4-1/2 DP to 5050. Monitor H2O \& flow well. Haul in 4-1/2" DP \& clean box \& pin } \\
\text { ends. Measure \& pickup 4-1/2" DP to } 6300 \text { '. POH from } 6300 \text { to } 5050 \text {. Install 4-1/2" DP, } \\
\text { safety valve \& close steel Ram's. Secure NCPA Drill Rig. }\end{array}$ \\
\hline $10 / 26 / 2000$ & $\begin{array}{l}\text { Make up subs \& rig-up Pruett wireline to log. Hold safety meeting with Pruett. RIH with } \\
\text { sinker bar \& 2-1/4 ring gauge tool on bottom to check hole condition. Stop @ 5130'. POH } \\
\text { with wireline \& break off ring gauge tool. Makeup bull nose took \& RIH. Bull-nose depth } \\
@ 6250^{\prime} \text {. POH \& break bull-nose tool. Makeup TPS tool \& RIH to 6250'. POH \& rig down } \\
\text { Pruett. POH \& close in well \& secure NCPA rig. }\end{array}$ \\
\hline $10 / 27 / 2000$ & $\begin{array}{l}\text { Perforate } 4 \text { jts. Of 4-1/2" DP counting mule shoe. Open well \& flow. Makeup mule shoe } \\
\text { perf. Jt. \& install used ROT Rubber. RIH } 4 \text { jts. of perforate pipe counting muleshoe. RIH, } \\
\text { stop @ } 4936 \text { '. Work through ledge. RIH, stop @ 5212'. Work through ledge. RIH to } \\
6179 \text { '. Install DP safety valve to kill well. Attempt to kill well. Well won't kill. BOPE steel } \\
\text { Ram's leaking. Remove safety valve \& Rot. Rubber. Makeup DP landing doughnut \& } 1 \text { jt. } \\
\text { of 4-1/2" DP to land doughnut with. Have a safety meeting on landing doughnut, while well } \\
\text { is flowing. Up through BOPE stack. Attempt to land DP landing doughnut. Land doughnut } \\
\text { depth @ 6202'. Close in top 12" Master valve \& secure rig. }\end{array}$ \\
\hline $10 / 30 / 2000$ & \begin{tabular}{|l|} 
Clean on NCPA rig. \\
\end{tabular} \\
\hline $10 / 31 / 2000$ & \begin{tabular}{|l} 
Clean on NCPA Rig. \\
\end{tabular} \\
\hline $11 / 01 / 2000$ & $\begin{array}{l}\text { Startup rig \& nipple down BOPE. Rig down blooie \& muffler. Move blooie line and } \\
\text { muffler, muffler tank, \& muffler racks to E-site location with NTS truck \& crane service. } \\
\text { Secure NCPA rig. }\end{array}$ \\
\hline $11 / 02 / 2000$ & $\begin{array}{l}\text { Rig down NCPA Rig. Derrick layed over @ 1:00 p.m. Tear out rig \& secure NCPA rig. } \\
\text { NCPA Rig release @ 4:00 p.m. Rig is going to Calpine D\&V } \# 4 \text { 11/13/00. }\end{array}$ \\
\hline
\end{tabular}

